\title{
Obstacles to Implementing the Strategic Action Plan in the Light of Performance Evaluation at College of Education in Jeddah University
}

\author{
Mona A. Alfadli ${ }^{1, *}$ \\ ${ }^{1}$ Faculty of Education, University of Jeddah, Jeddah, Saudi Arabia \\ *Correspondence: Faculty of Education, University of Jeddah, Jeddah, Saudi Arabia. E-mail: Maalfadli@uj.edu.sa
}

Received: March 8, 2019

Accepted: April 2, $2019 \quad$ Online Published: April 12, 2019

doi:10.5430/wje.v9n2p73

URL: https://doi.org/10.5430/wje.v9n2p73

\begin{abstract}
The present study aims to investigate the obstacles to implementing the strategic action plan in the light of performance evaluation at the College of Education, Jeddah University. The author adopted the descriptive analytical approach. The population comprised all forms and documents relevant to the domains, namely learning and education, post-graduate studies, social responsibility, and funding. The results showed that the achievement rate of the domains was $40 \%, 18 \%, 0.04 \%$, and $73 \%$, respectively. The obstacles to learning and education related to awareness of the course and its design, difficulty of students' interaction, and form filling objectively. The obstacles to post-graduate studies domain were relevant to publishing in reviewed and standardized journals due to Jeddah University, lack of action handbook for mission and, post-graduate studies based on mission regulation of the Saudi Universities. The obstacles to social responsibility were relevant to funding in terms of allocating a budget for activating the social responsibility projects and upgrading the college's infrastructure. The obstacles to funding and investment were based on the needs of civil society associations to launch new programs that meet their needs and provide the College of Education with investment return.
\end{abstract}

Keywords: action plan, performance evaluation, college of education

\section{Introduction}

Currently, all institutions tremendously compete to achieve excellence, which requires evaluating their reality and reviewing their goals. Their current challenge is their disappearance or survival that is substantially based on planning. Planning is highly significant for the institutions, in general, and for education, in particular, to which the changes in all walks of life cannot be transferred directly and rapidly.

Planning processes are important administrative processes for educational institutions, especially in achieving their objectives and mission. That is, the preparation, implementation, follow-up, and evaluation of plans, programs as well as mechanisms achieve certain results utilizing the material and human resources available in the universities and the local community (Madbouli, 2002).

Planning comprises two types. While strategic planning is done at the top levels of the organizational structure, operational planning is done at the other levels (Sultan, 2010). Strategic planning is an element of the strategic management that is concerned with operational efficiency and linking thinking and implementing, as well as the strategy's design and implementation (Yasin, 2002). In other words, strategic management is concerned with the present and the future simultaneously. It analyzes the current status of the institution from a future perspective. Strategic planning is a systematic future process based on the inevitable and constant change, conceiving and formulating the future, and developing programs that take into account the opportunities, challenges, strengths, and weaknesses (Dessler, 2004). It helps diagnose reality as an essential step to propose a strategy for its development. It is also a part of analyzing the internal environment of the institution and identifying its strengths and weaknesses (John and Richard, 2011). That is, it provides a framework that helps the administration take rational decisions. Shuwaikh (2007) reports that the college seeks to achieve competitive advantage based on strategic planning. The college enhances this concept at all organizational levels. Al-Otaibi (2012) suggests that educational institutions constantly discuss the plan of improvement and quality within their strategic review, prioritizing improvement projects and constantly redesigning activities. Moreover, Al-Dajani (2011) concludes that there is a relationship 
between the role of strategic planning and the quality of institutional performance.

Operational planning is conducted in the executive departments and units. It assigns the tasks, detailed activities, timeline, as well as officer responsible for each task. The action plan, which lasts for one year or less, is carried out at the level of the supervisory management and executive units (Sultan, 2010). The strategic plan is fundamental for transforming the overall framework of the strategic attitude. The action plan, which is the final stage of the strategic plan, involves a detailed description of the required works. Operational planning defines the baselines of monitoring and evaluating organizational performance (Hamdan and Idris, 2009). Despite their theoretical difference, they share the same effect. Formulation might be poor because it is difficult to look forward. Effective implementation fills the gap in the formulation process. If formulation and implementation are poor, failure is expected. The vision of the strategic plan focuses on the overall level and it is less comprehensive in the action plan. In addition, the operational actions of the strategic plan are less compared to those of the action plan (Hamdan \& Idris, 2009).

Institutions should evaluate the outcomes of their work to associate the individuals' performance with their goals and strategies because what can be evaluated can be performed. Performance evaluation is the strategic control stage. It is the sixth stage of strategic planning at the level of the individual, organizational unit, or institution. It is also the total outcome of its achievement (Al-Mardi, 2016). It requires comparing the expected outcomes with realistic ones. Then, an evaluation is carried out to define where the institution has to conclude corrective results. Evaluators should take into account that differences in the assessment are associated with other factors.

Shawish (2005) claims that performance evaluation is a complex process in which several entities and factors are intertwined. Therefore, evaluators must thoroughly carry it out and follow logical sequential steps in order to achieve the goals of performance evaluation.

Institutional performance means the rate of achieving the expected goals. Thus, an institution can identify the domains that require more focus on achieving a positive impact. Performance evaluation defines the institution's competence in investing its available resources and helps make administrative decisions. That is, performance indicators involve effectiveness indicators of goals achievement, efficiency indicators of using resources, indicators of units' outcomes according to the relationship between inputs and outputs, as well as indicators of service quality. Effectiveness indicators, related to the goals of the activity under evaluation, are less complex than those of efficiency indicators. Goals are a direct indicator of efficiency effectiveness if they are quantitatively defined. Furthermore, effectiveness indicators provide us with information on the outcomes. Such indicators may be numbers, percentages, averages, or standard rates (Al-Mardi, 2016).

Goals identified quantitatively or quantitatively, are used as a tool for measuring the outcomes upon which evaluation is based. That is, performance evaluation and comparison of the expected outcomes with the realistic ones suggest that the institution needs to make corrective results because the overall goal is the outcome of the detailed partial goals (Al- Al-Mardi, 2016). Performance evaluation involves some difficulties, such as managers' unwillingness, lack of time and skills, wrong impression on the difficulties related to the system or information collection, poor budgets, poor dissemination of the plan among the departments, insufficient administrative needs, concern with quantity rather than quality, as well as lack of motivation and support for the plans (Hamdan and Idris, 2009).

The College of Education is well-established. It was established in 1974 and became under the umbrella of the Ministry of Higher Education, as one of the Colleges of King Abdulaziz University, in conjunction with the strategic orientation of the University in 2004. The second strategic plan was from 2011 to 2014 (Damanhoury, 2009). The third strategic plan" Enhancement" was launched in 2014-2025. It involves the domains of learning and education, post-graduate studies and scientific research, social responsibility and community service, funding and investment, quality and accreditation, as well as creativity and innovation.

Good action plans can overcome the challenges facing education. However, preparation of action plans in the educational institutions involves problems and obstacles that limit its effectiveness (Ministry of Education, 2013). Consequently, it recommends conducting various studies and researches on the aspects and domains of planning. Darakka (2009) states that educational planning encounters several obstacles and problems that hinder its role in developing and implementing plans.

The major goal of action plans is to define what should be conducted to achieve the strategic and detailed goals, as well as testing the validity of implementing the strategic plan. The goals are usually set in accordance with the desired results without verifying that they are achievable. Action plans involve the following realistic bases: The institution's ability to achieve the goals within the available timeline, knowledge, and skill required to implement the 
plan, accessibility to the necessary and substantial information, and availability of alternatives (General Administration of Planning and Administrative Development, 2015).

\section{Review of Literature}

Pieces of literature review have addressed this topic because of its importance. For example, Al-Shathri (2013) reported that the universities had to develop their strategic plans according to the results of performance evaluation.

Sterling (2003) highlighted how Rubicon Group Holding succeeded in using strategic focus. The results showed seven key reasons for strategy failure: Unanticipated market changes, insufficient resources, and lack of focus. That is, resources are wastefully dissipated if priorities are unclear. The preventative actions taken involved effective competitor responses to strategy and competitive intelligence. Cowburn (2005) investigated the process of strategic planning in British higher education institutions. The results indicated that the British Universities did not apply strategic planning due to the lack of available financial resources and duplication of the decision. Additionally, the lack of realistic plans and definite objectives resulted in the failure of planning processes. Al-Afif (2005) showed that the factors influencing strategic planning among senior and intermediate administrators in the Jordanian public departments were the lack of human competencies, funding, information, technology, as well as old legislation.

Al-Shuboul (2005) showed financial, administrative, and technical obstacles to the implementation of strategic management. Moreover, Abu Eisha (2007) indicated that material resources were highly relevant to educational planning. Al-Hammaly and Al-Araby (2013) revealed the lack of a committee overseeing strategic planning at the University level, lack of human cadres, and resistance of some officials and employees to change.

Al-Looh (2007) showed a statistically significant relationship between the availability of strategic planning and the obstacles to its implementation. Hoffman (2007) showed that there was a relationship between strategic planning and performance. Additionally, Rudd, Greenley, and Beatson (2007) reported that strategic planning directly and positively affected structural planning that affected non-financial performance. In addition, strategic planning directly and positively affected technological flexibility that affected performance.

There is a constant need for evaluating the performance of educational institutions, especially universities. For example, Abu Sheikha (2005) and Poon (2003) indicated that there are obstacles to performance evaluation in relation to the evaluation and the evaluator. Al-Fadli (2014) evaluated the quality of teaching and learning at the College of Education, King Abdulaziz University. The results showed that the quality of teaching and learning was moderate and there was a need for improvement and change, which may encounter resistance or difficulties related to infrastructure.

This review showed that many studies addressed strategic planning, especially the obstacles associated with the performance evaluation of action or strategic plans. Consequently, the author handles operational planning, a domain of strategic planning, in higher education institutions which have to exert their utmost efforts in the light of the present challenges.

\section{Statement of the Problem}

The problem of the present study is formulated in the following major question:

What are the obstacles to implementing the strategic action plan in the light of performance evaluation at the College of Education, Jeddah University?

It can be subdivided into the following minor ones:

1. To what extent are performance indicators of learning and education domain achieved according to the follow-up form of the implementation of the action plan?

2. To what extent are performance indicators of post-graduate studies domain achieved according to the follow-up form of the implementation of the action plan?

3. To what extent are performance indicators of social responsibility domain achieved according to the followup form of the implementation of the action plan?

4. To what extent are performance indicators of funding and investment domain achieved according to the follow-up form of the implementation of the action plan? 


\section{Objectives}

The present study aims to identify the obstacles to implementing the strategic action plan in the light of performance evaluation at the College of Education, Jeddah University through:

1. Identifying the rates of achieving performance indicators of learning and education projects according to the follow-up form of the implementation of the action plan.

2. Identifying the rates of achieving performance indicators of post-graduate studies projects according to the follow-up form of the implementation of the action plan.

3. Identifying the rates of achieving performance indicators of social responsibility projects according to the follow-up form of the implementation of the action plan.

4. Identifying the rates of achieving performance indicators of funding and investment projects according to the follow-up form of the implementation of the action plan.

\section{Significance}

The present study is significant because it evaluates the final action plan of the College of Education before being an affiliation to Jeddah University and helps the College of Education develop its action plan in the light of the strategic plan of Jeddah University. It also investigates the obstacles to its implementation. It involves the following aspects:

- It provides feedback on the rates of implementing the projects of the action plan domains and identifies the improvement opportunities.

- It demonstrates the need to improve the infrastructure essential for implementing the University's strategic orientations and indicators.

- It disseminates the culture of strategic planning at the College of Education and highlights the importance of the strategic domains to strengthen the attitude towards their importance and implementation.

- It analyzes the reality, strengths, and weaknesses of the internal strategic environmental at the College of Education.

- Investigating the obstacles to the implementation of the strategic plan is a response to the orientation of universities, in general, towards strategic planning.

\section{Limitations}

Objective limitations: The present study investigates the obstacles to implementing the strategic action plan in the light of performance evaluation at the College of Education, Jeddah University. It comprises (5) projects of learning and education, (4) projects of post-graduate studies, (3) projects of social responsibility and community service, and (2) projects of funding and investment.

Temporal Limitations: 2015-2016 was the final action plan prepared by the College of Education in the light of the strategic plan when it was separated from King Abdulaziz University and was affiliated to Jeddah University.

\section{Definition of Terms}

Obstacles: They are defined as the difficulties, which impede implementing the strategic planning and achieving the objectives of the strategic plan (Al-Atawi, 2013).

They are procedurally defined as the material, human, and cognitive deficiency or need that is substantial for achieving the strategic plan of the College of Education, Jeddah University.

Performance evaluation: It is a process of comparing an actual reality (achieved performance) and targeted criteria, scales, rates, and indicators (targeted performance) to make sure of what has been accomplished (Mostafa, 2014).

Action plan: It is a framework that involves a number of activities and programs to be implemented by the executive departments within a definite timeline based on goals with financial estimates (Al-Awshen, 2013).

It is procedurally defined as a framework that involves four projects, namely learning and education, post-graduate studies, social responsibility, as well as finance and investment; indicators to evaluate their implementation within one year; rates of achievement. 


\section{Methodology}

\subsection{Method}

The author adopted the descriptive analytical approach because it is appropriate for the nature of the study, and it helps identify, analyze, and explain the reality of performance evaluation of the action plan at present and in the near future. This approach is relevant to the surveys and data collection, especially the official written documents that describe a definite educational phenomenon. Furthermore, their content should be analyzed in order to obtain conclusions or generalizations on the situation (Awda and Malakawi, 1992).

\subsection{Population}

The population comprises the forms, documents, and information collected from the forms of strategic plan projects, action plan, and follow-up of the action plan implementation at the Strategic Planning Unit of the College.

\subsection{Tools}

- A form of action plan projects and their achievement indicators (Appendix 1).

- Follow-up form of the action plan implementation (prepared by the author) (appendix 2).

- A list of the projects of the strategic plan "Enhancement ".

The two forms were designed after:

- Reviewing literature on action plans preparation and performance evaluation.

- Reviewing the forms of follow-up of action plan implementation and performance evaluation.

Accordingly, the form was prepared and comprised the four domains of the strategic plan, namely learning and education, post-graduate studies, social responsibility, and community service, as well as funding and investment. Each project had a program involving performance indicators and assessment unit of each indicator indicating the rate of achievement in each indicator and project.

\subsection{Validity}

The validity of the tool was verified by:

- The validity of the reviewers: The forms of the action plan content in the light of the third strategic plan were reviewed by (5) specialized faculty members to evaluate how far the programs, indicators, and measurements matched the projects.

\subsection{Procedures}

The information related to the domains of the strategic plan projects was collected and distributed in the follow-up form, measurements of each indicator were estimated, their achievement was evaluated, and suggestions for implementing each domain were stated.

\section{Results and Discussion}

\subsection{Results of the First Question}

In order to answer this question, frequencies and percentages of performance indicators of learning and education domain were estimated, as shown in tables (1), (1-2), (1-3), (1-4), (1-5), and (1-6).

Tables (1), (1-2), (1-3), (1-4), (1-5), and (1-6) show that the achievement of the digital measurements of learning and education was rated $40 \%$.

- Applying the student evaluation mechanism to the quality of the course, faculty member, laboratories, and services was rated $(36 \%)$ and the achievement indicators rate ranged $(0 \%-100 \%)$. Some indicators were rated low due to the lack of awareness of the importance of the course portfolio which is essential for developing the material, some students' failure to fill in the form, unavailability of a unified body that creates and analyzes the form and provides feedback, and not measuring the indicators which had no special form.

- The project of developing the quality of practicing the scientific training course with distinguished sectors off campus was rated $(100 \%)$.

- The project of organizing a ceremony for the outstanding faculty members was rated (88\%) and the achievement indicators rate ranged $(0 \%-100 \%)$. This resulted from the need for financial support and a competent body to 
manage it at the university, the College of Education's separation from King Abdulaziz University, and the need for more time to organize the structure and tasks.

- The project of publicizing the regulation of the student rights and discipline at the college for the employees was rated $(100 \%)$ and the achievement indicators rate ranged $(0 \%-100 \%)$. Some indicators were rated low due to lack of measurement units which were under construction or preparation.

- The project of organizing a ceremony for the outstanding students in each scientific department and level was rated $(100 \%)$, and the achievement indicators were rated $(100 \%)$.

Table 1. Rate of Achieving the Performance Indicators of Learning and Education Projects

\begin{tabular}{|c|c|c|c|}
\hline Project & Title & Program & Achievement \\
\hline M1 B1 Sh17 & $\begin{array}{l}\text { Applying the student evaluation mechanism } \\
\text { to the quality of the course, faculty member, } \\
\text { laboratories, and services. }\end{array}$ & $\begin{array}{l}\text { Conducting students' evaluation of the } \\
\text { quality of the course, faculty member, } \\
\text { laboratories, and services. }\end{array}$ & $36 \%$ \\
\hline M1 B1 Sh20 & $\begin{array}{l}\text { Developing the quality of practicing the } \\
\text { scientific training course with distinguished } \\
\text { sectors off campus. }\end{array}$ & $\begin{array}{l}\text { Setting the criteria for developing the quality } \\
\text { of practicing the scientific training course } \\
\text { with distinguished sectors off campus. }\end{array}$ & $100 \%$ \\
\hline M1 B1 Sh18 & $\begin{array}{l}\text { Organizing a ceremony for the outstanding } \\
\text { faculty members. }\end{array}$ & $\begin{array}{l}\text { Organizing a ceremony for the outstanding } \\
\text { faculty members, lecturers, and technicians. }\end{array}$ & $88 \%$ \\
\hline M1 B1 Sh25 & $\begin{array}{l}\text { Publicizing the regulation of the student } \\
\text { rights and discipline at the college for the } \\
\text { employees. }\end{array}$ & $\begin{array}{l}\text { Publicizing the regulation of the student } \\
\text { rights and discipline at the college for the } \\
\text { employees. }\end{array}$ & $100 \%$ \\
\hline M1 B1 Sh19 & $\begin{array}{l}\text { Organizing a ceremony for the outstanding } \\
\text { students in each scientific department and } \\
\text { level. }\end{array}$ & $\begin{array}{l}\text { Organizing awards ceremony for the } \\
\text { outstanding students. }\end{array}$ & $100 \%$ \\
\hline \multicolumn{3}{|c|}{ Overall achievement } & $40 \%$ \\
\hline
\end{tabular}

Table (1-2). Rates of Achieving the Performance Indicators of the Project of Applying the Student Evaluation Mechanism of the Quality of the Course, Faculty Member, Laboratories, and Services

\begin{tabular}{|c|c|c|c|c|c|c|c|c|}
\hline \multirow[t]{2}{*}{ No. } & \multirow[t]{2}{*}{ Project } & \multirow[t]{2}{*}{ Program } & \multirow[t]{2}{*}{ Performance indicators } & \multicolumn{3}{|c|}{ Indicator Measurements } & \multicolumn{2}{|c|}{ Achievement Rate } \\
\hline & & & & Required & Unit & Achieved & Indicator & Project \\
\hline \multirow{10}{*}{$\begin{array}{l}\text { M1 } \\
\text { B1 } \\
\text { Sh17 }\end{array}$} & \multirow{10}{*}{$\begin{array}{l}\text { Applying } \\
\text { the student } \\
\text { evaluation } \\
\text { mechanism } \\
\text { of the } \\
\text { quality of } \\
\text { the course, } \\
\text { faculty } \\
\text { member, } \\
\text { laboratories, } \\
\text { and services }\end{array}$} & \multirow{10}{*}{$\begin{array}{l}\text { Conducting } \\
\text { student } \\
\text { evaluation } \\
\text { of the } \\
\text { quality of } \\
\text { the course, } \\
\text { faculty } \\
\text { member, } \\
\text { laboratories, } \\
\text { and } \\
\text { services. }\end{array}$} & Course Portfolio & 98 & Portfolio & 57 & $58 \%$ & $36 \%$ \\
\hline & & & Questionnaire of the & 603 & Questionnaire & 375 & $62 \%$ & \\
\hline & & & $\begin{array}{l}\text { students' evaluation of the } \\
\text { course }\end{array}$ & & & & & \\
\hline & & & $\begin{array}{l}\text { Questionnaire of the } \\
\text { stakeholders' satisfaction } \\
\text { with the program of Special } \\
\text { Education }\end{array}$ & 175 & Questionnaire & 72 & $41 \%$ & \\
\hline & & & $\begin{array}{l}\text { Questionnaire of the } \\
\text { students evaluation of } \\
\text { electronic services }\end{array}$ & 603 & Questionnaire & 168 & $28 \%$ & \\
\hline & & & $\begin{array}{l}\text { Questionnaire of the } \\
\text { students' evaluation of the } \\
\text { field training (Special } \\
\text { Education) }\end{array}$ & 176 & Questionnaire & 176 & $100 \%$ & \\
\hline & & & $\begin{array}{l}\text { Questionnaire of the } \\
\text { students' evaluation of the } \\
\text { field training from the Unit }\end{array}$ & 176 & Questionnaire & - & $0 \%$ & \\
\hline & & & $\begin{array}{l}\text { of Measurement \& } \\
\text { Evaluation }\end{array}$ & & & & & \\
\hline & & & $\begin{array}{l}\text { Evaluation questionnaire of } \\
\text { students' performance. }\end{array}$ & 603 & Questionnaire & - & $0 \%$ & \\
\hline & & & $\begin{array}{l}\text { Enhancing distance and e- } \\
\text { learning through courses }\end{array}$ & 13 & Course & 13 & $100 \%$ & \\
\hline
\end{tabular}


Table (1-3). Rates of Achieving the Performance Indicators of the Project of Developing the Quality of Applying the Practicum to with Distinguished Sectors off Campus

\begin{tabular}{|c|c|c|c|c|c|c|c|c|}
\hline \multirow[t]{2}{*}{ No. } & \multirow[t]{2}{*}{ Project } & \multirow[t]{2}{*}{ Program } & \multirow{2}{*}{$\begin{array}{l}\text { Performance } \\
\text { indicators }\end{array}$} & \multicolumn{3}{|c|}{ Indicator Measurements } & \multicolumn{2}{|c|}{ Achievement Rate } \\
\hline & & & & Required & Unit & Achieved & Indicator & Project \\
\hline \multirow{9}{*}{$\begin{array}{l}\text { M1 } \\
\text { B1 } \\
\text { Sh20 }\end{array}$} & \multirow{6}{*}{$\begin{array}{l}\text { Developing } \\
\text { the quality of } \\
\text { applying the } \\
\text { practicum } \\
\text { course to } \\
\text { distinguished }\end{array}$} & \multirow{8}{*}{$\begin{array}{l}\text { Defining the } \\
\text { criteria for } \\
\text { developing the } \\
\text { quality of } \\
\text { applying the } \\
\text { practicum } \\
\text { course to } \\
\text { distinguished }\end{array}$} & \multirow{8}{*}{$\begin{array}{l}\text { Preparation of a } \\
\text { form defining the } \\
\text { stakeholder's } \\
\text { satisfaction (public } \\
\text { schools and private } \\
\text { centers, such as } \\
\text { Alawn Center and } \\
\text { Jesh Center) }\end{array}$} & \multirow[t]{8}{*}{1} & \multirow[t]{8}{*}{ Form } & \multirow[t]{8}{*}{1} & \multirow[t]{8}{*}{$100 \%$} & \multirow[t]{9}{*}{$100 \%$} \\
\hline & & & & & & & & \\
\hline & & & & & & & & \\
\hline & & & & & & & & \\
\hline & & & & & & & & \\
\hline & & & & & & & & \\
\hline & \multirow{3}{*}{$\begin{array}{l}\text { sectors off } \\
\text { campus }\end{array}$} & & & & & & & \\
\hline & & & & & & & & \\
\hline & & $\begin{array}{l}\text { sectors off } \\
\text { campus }\end{array}$ & $\begin{array}{l}\text { Application of the } \\
\text { form of evaluating } \\
\text { the practicum course }\end{array}$ & 175 & Form & 175 & $100 \%$ & \\
\hline
\end{tabular}

Table (1-4). Rates of Achieving the Performance Indicators of Organizing a Ceremony for the Outstanding Faculty Members

\begin{tabular}{|c|c|c|c|c|c|c|c|c|}
\hline \multirow[t]{2}{*}{ No. } & \multirow[t]{2}{*}{ Project } & \multirow[t]{2}{*}{ Program } & \multirow{2}{*}{$\begin{array}{l}\text { Performance } \\
\text { indicators }\end{array}$} & \multicolumn{3}{|c|}{ Indicator Measurements } & \multicolumn{2}{|c|}{ Achievement Rate } \\
\hline & & & & Required & Unit & Achieved & Indicator & Project \\
\hline \multirow{16}{*}{$\begin{array}{l}\text { M1 } \\
\text { B1 } \\
\text { Sh18 }\end{array}$} & \multirow{16}{*}{$\begin{array}{l}\text { Organizing a } \\
\text { ceremony for } \\
\text { the } \\
\text { outstanding } \\
\text { faculty } \\
\text { members. }\end{array}$} & \multirow{16}{*}{$\begin{array}{l}\text { Organizing a } \\
\text { ceremony for } \\
\text { the } \\
\text { outstanding } \\
\text { faculty } \\
\text { member, } \\
\text { lecturers, and } \\
\text { technicians }\end{array}$} & Preparing & 11 & \multirow[t]{2}{*}{ Course } & \multirow[t]{2}{*}{11} & \multirow[t]{2}{*}{$100 \%$} & \multirow[t]{16}{*}{$88 \%$} \\
\hline & & & $\begin{array}{l}\text { infrastructure and } \\
\text { trainers as well as } \\
\text { training the faculty } \\
\text { employees in the } \\
\text { field of e-learning }\end{array}$ & & & & & \\
\hline & & & $\begin{array}{l}\text { A ceremony at the } \\
\text { end of the semester }\end{array}$ & 1 & \multirow{14}{*}{$\begin{array}{c}\text { Award } \\
\text { ceremony } \\
\text { form }\end{array}$} & $0 \%$ & $0 \%$ & \\
\hline & & & $\begin{array}{l}\text { Defining criteria for } \\
\text { selecting the } \\
\text { distinguished } \\
\text { faculty members. }\end{array}$ & 1 & & $0.5 \%$ & \multirow[t]{13}{*}{$50 \%$} & \\
\hline & & & Design $\quad a$ & & & & & \\
\hline & & & questionnaire that & & & & & \\
\hline & & & measures the & & & & & \\
\hline & & & criteria required to & & & & & \\
\hline & & & evaluate the & & & & & \\
\hline & & & outstanding faculty & & & & & \\
\hline & & & members & & & & & \\
\hline & & & (obtaining & & & & & \\
\hline & & & excellence criteria & & & & & \\
\hline & & & from the evaluation & & & & & \\
\hline & & & form of the faculty & & & & & \\
\hline & & & members) & & & & & \\
\hline
\end{tabular}


Table (1-5). Rates of Achieving the Performance Indicators of Publicizing the Regulation of the Student's Rights and Discipline at the College among the Employees

\begin{tabular}{|c|c|c|c|c|c|c|c|c|}
\hline \multirow[t]{2}{*}{ No. } & \multirow[t]{2}{*}{ Project } & \multirow[t]{2}{*}{ Program } & \multirow{2}{*}{$\begin{array}{l}\text { Performance } \\
\text { indicators }\end{array}$} & \multicolumn{3}{|c|}{ Indicator Measurements } & \multicolumn{2}{|c|}{ Achievement Rate } \\
\hline & & & & Required & Unit & Achieved & Indicator & Project \\
\hline M1 & Publicizing & Publicizing & Holding annual & 1 & Meeting & 1 & $100 \%$ & $100 \%$ \\
\hline B1 & the regulation & the regulation & meetings with the & & & & & \\
\hline \multirow[t]{7}{*}{$\operatorname{Sh} 25$} & of the & of the & students to know & & & & & \\
\hline & student's & student's & their duties and & & & & & \\
\hline & rights and & rights and & rights & & & & & \\
\hline & discipline at & discipline at & & & & & & \\
\hline & the college & the college & & & & & & \\
\hline & among the & and among the & & & & & & \\
\hline & employees & employees & & & & & & \\
\hline
\end{tabular}

Table (1-6). Rates of Achieving the Performance Indicators of Organizing a Ceremony for the Outstanding Students in Each Level and Scientific Department

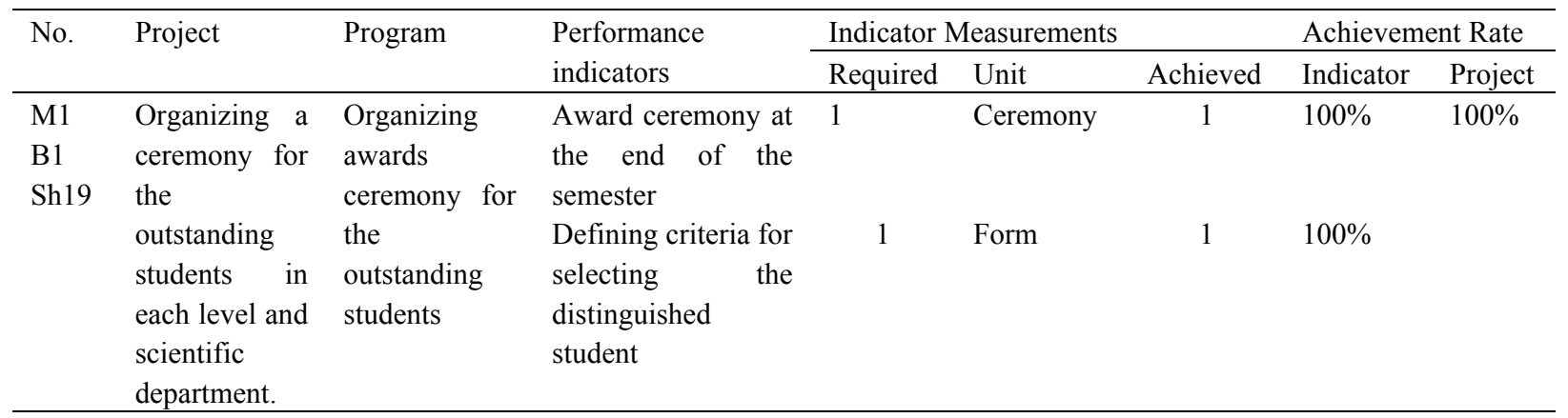

Learning and education domain is one of the most important domains in which the University seeks distinction. It is the basis for the strategic plan for the university which is keen on renewing and developing this domain. However, there are difficulties in the implementation or resistance to change which requires culture dissemination, constant training, faculty members' awareness of the importance of its implementation, and suggesting new beneficial methods. This result is consistent with Al-Fadli (2014), suggesting that the quality of teaching and learning was moderate and there was a need for development and change. It matches the findings of Al-Otaibi (2012), reporting that the educational institutions constantly discuss the plan of improvement and quality within the strategic review of the institution. Additionally, it matches the results of Sterling (2003) that the strategy wasn't implemented because the institutions underwent unexpected changes. The result of this domain is associated with the College of Education's affiliation to Jeddah University which coincided with the implementation of the action plan.

\subsection{Results of the Second Question}

In order to answer this question, frequencies and percentages of performance indicators of post-graduate studies domain were estimated, as shown in tables (2), (2-1), (2-2), (2-3), and (2-4).

Tables (2), (2-1), (2-2), (2-3), and (2-4) show that the achievement of the measurements of the post-graduate studies domain was rated $18.3 \%$.

- The project of Increase the scientific publication of the university (an article annually published by the faculty member in ISI Journal) was rated (17\%) and the achievement indicators rate ranged $(0 \%-100 \%)$. Some indicators were rated low due to the lack of a database for the faculty members' researches as well as their commitments with other institutions, not activating the committee of the College of Education Journal, faculty members' low level in the English language, or the high cost of publishing papers in ISI.

- The project of Support the demonstrators to get opportunities in the internationally distinguished universities (the top 200 universities) was rated (47\%) and the achievement indicators rate ranged ( $0 \%-100 \%)$. Some indicators were rated low or were not achieved due to lack of an action handbook of scholarships, incompleteness of Jeddah University website, inaccessibility to the well-established universities on the Internet, 
as well as lack of providing Jeddah University students with courses because of the delayed utilization of technology and difficulty of carrying out the tasks manually.

- The project to developing the mechanism of increasing the publications of the post-graduate students was rated $(1.8 \%)$ and the achievement indicators rate ranged ( $0 \%-100 \%)$. Some indicators rated low or were not achieved due to lack of a scientific research committee that supports or offers facilities to researchers.

- The project of activating seminars (seminars for post-graduate students at the College) was rated (40\%) and the achievement indicators rate was $(40 \%)$.

Table 2. Rate of Achieving the Performance Indicators of Post-Graduate Projects

\begin{tabular}{|c|c|c|c|}
\hline Project & Title & Program & Achievement \\
\hline M2 B5 Sh2 & $\begin{array}{l}\text { Increase the scientific publication of } \\
\text { the university (an article annually } \\
\text { published by the faculty member in } \\
\text { ISI Journal) }\end{array}$ & $\begin{array}{l}\text { Develop scientific research and increase the } \\
\text { publications } \\
\text { of faculty members }\end{array}$ & $17 \%$ \\
\hline M2 B5 Sh3 & $\begin{array}{l}\text { Support the demonstrators to get } \\
\text { opportunities in the internationally } \\
\text { distinguished universities (the top } 200 \\
\text { universities) }\end{array}$ & $\begin{array}{l}\text { Prepare the demonstrators to get opportunities } \\
\text { in the internationally distinguished universities }\end{array}$ & $47 \%$ \\
\hline $\begin{array}{l}\text { M2 B6 } \\
\text { Sh12 }\end{array}$ & $\begin{array}{l}\text { Develop the mechanism of increasing } \\
\text { the publications of the post-graduate } \\
\text { students }\end{array}$ & $\begin{array}{l}\text { Raise the post- graduate students' competence } \\
\text { in scientific research }\end{array}$ & $1.81 \%$ \\
\hline $\begin{array}{l}\text { M2 B6 } \\
\text { Sh13 }\end{array}$ & $\begin{array}{l}\text { Activating seminars (seminars for } \\
\text { post-graduate students at the College) }\end{array}$ & $\begin{array}{l}\text { Commitment to activate the seminars at the } \\
\text { department and define standards to activate } \\
\text { them. }\end{array}$ & $40 \%$ \\
\hline \multicolumn{3}{|c|}{ Overall achievement } & $18.34 \%$ \\
\hline
\end{tabular}

Table (2-1). Rate of Achieving the Performance Indicators of the Project of Raising the Scientific Publication of the University (an article annually published by the faculty member in ISI Journal)

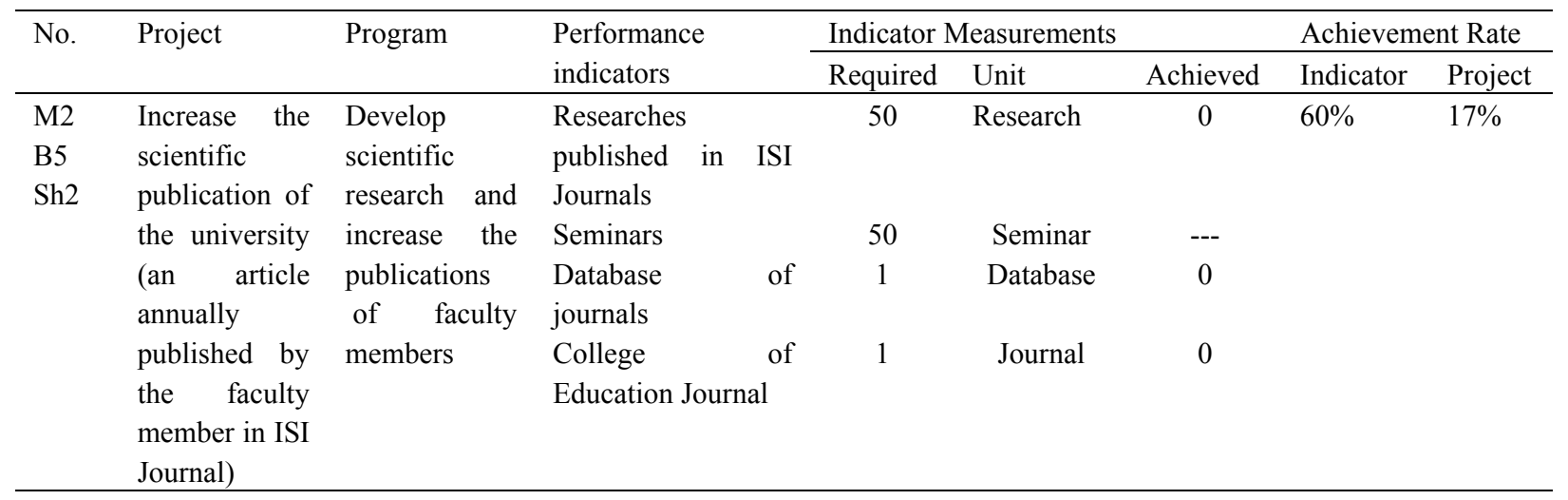


Table (2-2). Rate of Achieving the Performance Indicators of the Project of Support the Demonstrators to Get Opportunities in the Internationally Distinguished Universities (the top 200 universities)

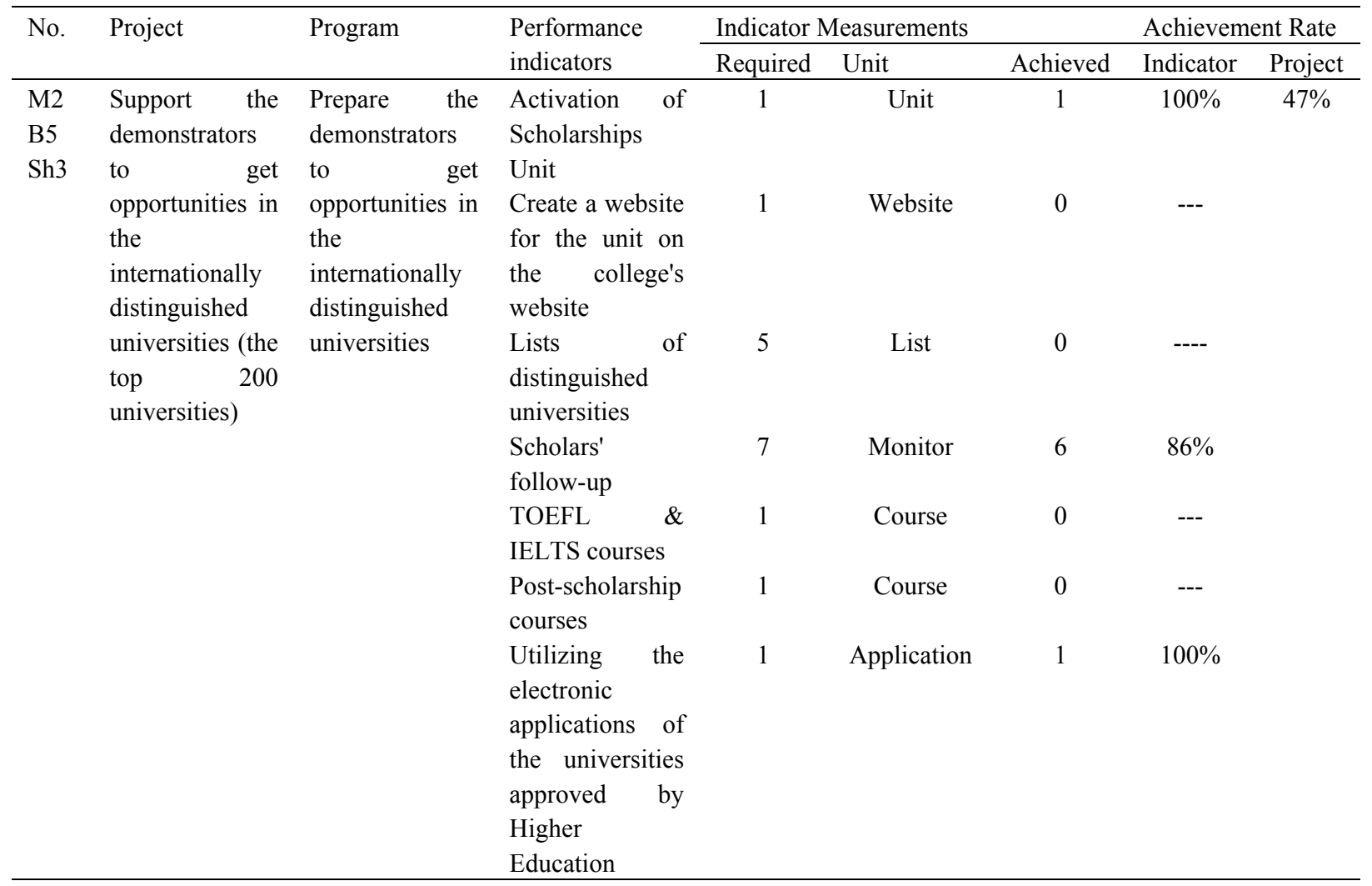

Table (2-3). Rate of Achieving the Performance Indicators of the Project of Developing the Mechanism of Increasing the Publications of the Post-Graduate Students

\begin{tabular}{|c|c|c|c|c|c|c|c|c|}
\hline \multirow[t]{2}{*}{ No. } & \multirow[t]{2}{*}{ Project } & \multirow[t]{2}{*}{ Program } & \multirow{2}{*}{$\begin{array}{l}\text { Performance } \\
\text { indicators }\end{array}$} & \multicolumn{3}{|c|}{ Indicator Measurements } & \multicolumn{2}{|c|}{ Achievement Rate } \\
\hline & & & & Required & Unit & Achieved & Indicator & Project \\
\hline \multirow{11}{*}{$\begin{array}{l}\text { M2 } \\
\text { B6 } \\
\text { Sh12 }\end{array}$} & \multirow{11}{*}{$\begin{array}{l}\text { Develop the } \\
\text { mechanism of } \\
\text { increasing the } \\
\text { publications } \\
\text { of the post- } \\
\text { graduate } \\
\text { students }\end{array}$} & \multirow{11}{*}{$\begin{array}{l}\text { Raise the } \\
\text { post- graduate } \\
\text { students' } \\
\text { competence } \\
\text { in scientific } \\
\text { research }\end{array}$} & A committee to & 1 & Committee & 0 & - & $1.8 \% \mathrm{~S}$ \\
\hline & & & investigate the & & & & & \\
\hline & & & & & & & & \\
\hline & & & researches. & & & & & \\
\hline & & & Courses & 3 & Course & 1 & $33 \%$ & \\
\hline & & & workshops to & & & & & \\
\hline & & & develop scientific & & & & & \\
\hline & & & research skill & & & & & \\
\hline & & & Database for the & 1 & Database & 0 & - & \\
\hline & & & $\begin{array}{l}\text { post-graduate } \\
\text { students and their } \\
\text { researches }\end{array}$ & & & & & \\
\hline & & & $\begin{array}{l}\text { Marketing the } \\
\text { creative papers of } \\
\text { the post-graduate } \\
\text { students }\end{array}$ & 50 & $\begin{array}{c}\text { Research } \\
\text { project }\end{array}$ & 0 & - & \\
\hline
\end{tabular}


Table (2-4). Rate of Achieving the Performance Indicators of the Post-Graduate Studies Project (activating seminars for the post-graduate students at the College)

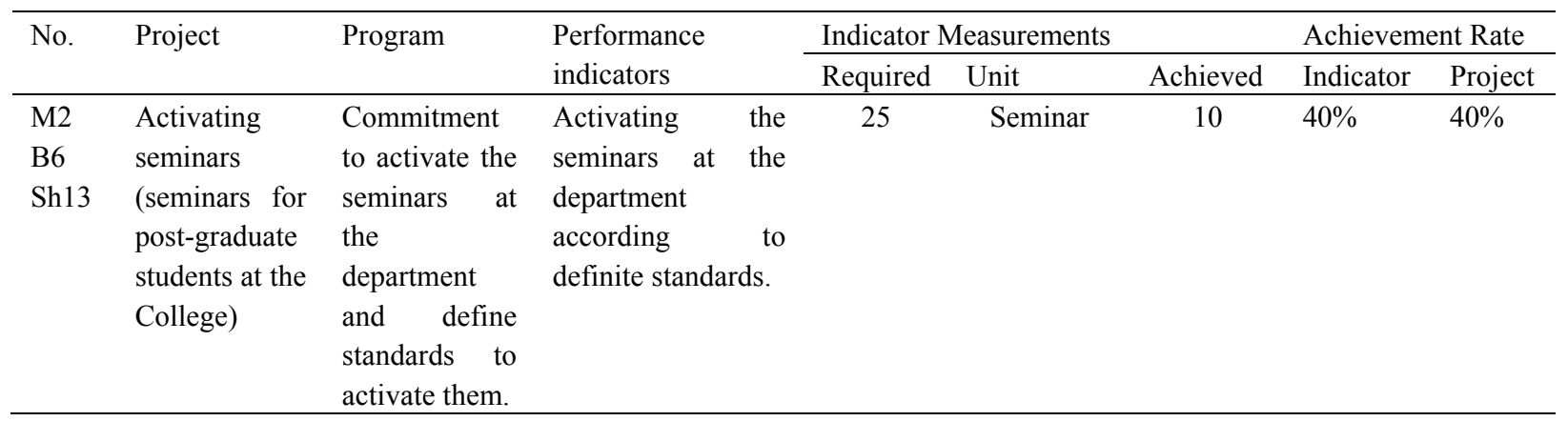

Results of the second domain are associated with the schedule of post-graduate students, difficulty of defining appointments accepted by all students, and lack of an action handbook of post-graduate studies and scholarships. This result is consistent with Rudd Greenley, and Beatson (2007), reporting that strategic planning directly and positively affected structural planning that affected non-financial performance. It is also consistent with the findings of Sterling (2003) that the failure of strategies associated with the insufficient databases that meet the needs of information, unexpected changes, insufficient resources, and administration's inability to define priorities. In addition, the result of this domain is associated with the College of Education's affiliation to Jeddah University which requires restructuring the management that may take time.

\subsection{Results of the Third Question}

In order to answer this question, frequencies and percentages of performance indicators of social responsibility domain were estimated, as shown in tables (3), (3-1), (3-2), and (3-3).

Table 3. Rate of Achieving the Performance Indicators of Social Responsibility Projects

\begin{tabular}{|c|c|c|c|}
\hline Project & Title & Program & Achievement \\
\hline M3 B9 Sh1 & $\begin{array}{l}\text { Offering award for the best } \\
\text { participation by a department, faculty } \\
\text { member, or administrator }\end{array}$ & $\begin{array}{l}\text { Offering award for the best participation by a } \\
\text { department, faculty member, or administrator to } \\
\text { community service. }\end{array}$ & $0 \%$ \\
\hline $\begin{array}{l}\text { M3 B10 } \\
\text { Sh3 }\end{array}$ & $\begin{array}{l}\text { Activating the program of the school } \\
\text { students' full-day visit to the College }\end{array}$ & $\begin{array}{l}\text { Organizing a field visit by the high school } \\
\text { students to the College. }\end{array}$ & $0 \%$ \\
\hline $\begin{array}{l}\text { M3 B10 } \\
\text { Sh13 }\end{array}$ & $\begin{array}{l}\text { Conducting a project related to } \\
\text { community service (problem-solving) }\end{array}$ & $\begin{array}{l}\text { Defining distinct projects that benefit the } \\
\text { community }\end{array}$ & $0.04 \%$ \\
\hline \multicolumn{3}{|c|}{ Overall achievement } & $0.04 \%$ \\
\hline
\end{tabular}

Table (3-1). Rate of achieving the performance indicators of the project of offering an award for the Best Participation by a Department, Faculty Member, or Administrator

\begin{tabular}{|c|c|c|c|c|c|c|c|c|}
\hline \multirow[t]{2}{*}{ No. } & \multirow[t]{2}{*}{ Project } & \multirow[t]{2}{*}{ Program } & \multirow{2}{*}{$\begin{array}{l}\text { Performance } \\
\text { indicators }\end{array}$} & \multicolumn{3}{|c|}{ Indicator Measurements } & \multicolumn{2}{|c|}{ Achievement Rate } \\
\hline & & & & Required & Unit & Achieved & Indicator & Project \\
\hline $\begin{array}{l}\text { M3 } \\
\text { B9 } \\
\text { Sh1 }\end{array}$ & $\begin{array}{l}\text { Offering } \\
\text { award for the } \\
\text { best }\end{array}$ & $\begin{array}{l}\text { Offering } \\
\text { award for the } \\
\text { best }\end{array}$ & $\begin{array}{ll}\text { Arranging } & \text { award } \\
\text { ceremony } & \text { every } \\
\text { semester } & \end{array}$ & 1 & Ceremony & - & $0 \%$ & $0 \%$ \\
\hline & $\begin{array}{l}\text { participation } \\
\text { by a } \\
\text { department, } \\
\text { faculty } \\
\text { member, or } \\
\text { administrator }\end{array}$ & $\begin{array}{l}\text { participation } \\
\text { by a } \\
\text { department, } \\
\text { faculty } \\
\text { member, or } \\
\text { administrator } \\
\text { to community } \\
\text { service. }\end{array}$ & $\begin{array}{l}\text { Creating a form } \\
\text { that defines } \\
\text { excellence } \\
\text { standards. }\end{array}$ & 1 & Form & - & $0 \%$ & $0 \%$ \\
\hline
\end{tabular}


Table (3-2). Rate of Achieving the Performance Indicators of the Project of Activating the Program of the School Students' Full-Day Visit to the College

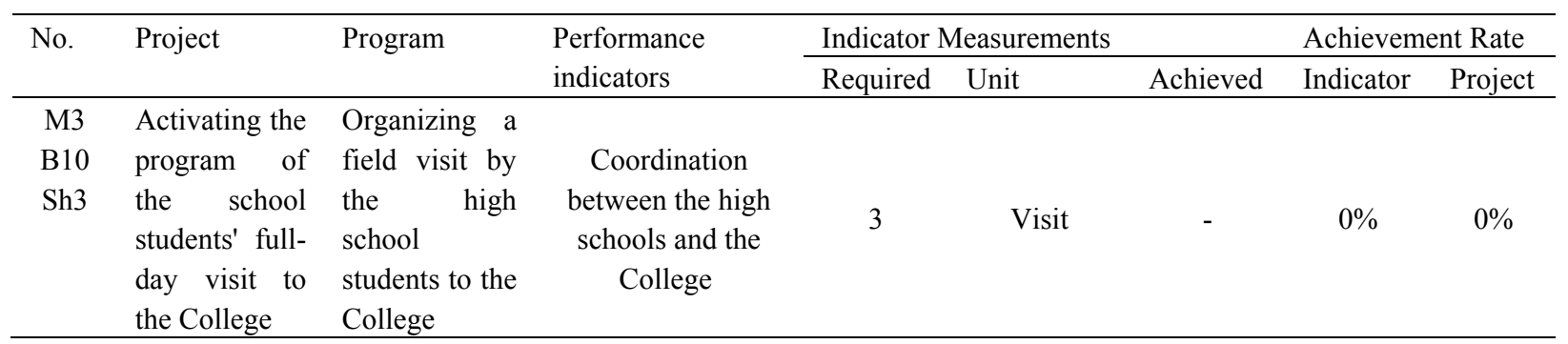

Table (3-3). Rate of Achieving the Performance Indicators of the Project of Conducting a Project Related to Community Service (problem-solving)

\begin{tabular}{|c|c|c|c|c|c|c|c|c|}
\hline \multirow[t]{2}{*}{ No. } & \multirow[t]{2}{*}{ Project } & \multirow[t]{2}{*}{ Program } & \multirow{2}{*}{$\begin{array}{l}\text { Performance } \\
\text { indicators }\end{array}$} & \multicolumn{3}{|c|}{ Indicator Measurements } & \multicolumn{2}{|c|}{ Achievement Rate } \\
\hline & & & & Required & Unit & Achieved & Indicator & Project \\
\hline \multirow{13}{*}{$\begin{array}{l}\text { M3 } \\
\text { B10 } \\
\text { Sh13 }\end{array}$} & \multirow{13}{*}{$\begin{array}{l}\text { Conducting a } \\
\text { project } \\
\text { related to } \\
\text { community } \\
\text { service } \\
\text { (problem- } \\
\text { solving) }\end{array}$} & \multirow{13}{*}{$\begin{array}{l}\text { Defining } \\
\text { distinct } \\
\text { projects that } \\
\text { benefit the } \\
\text { community }\end{array}$} & Preparing a study & & & & & \\
\hline & & & Arabic language & & & & & \\
\hline & & & and learn a & & & & & \\
\hline & & & foreign language". & & & & & \\
\hline & & & $\begin{array}{l}\text { Identifying } \\
\text { participation }\end{array}$ & 1 & Study & 1 & $100 \%$ & \\
\hline & & & $\begin{array}{l}\text { (faculty members, } \\
\text { post-graduate }\end{array}$ & & & & & \\
\hline & & & students, and & & & & & \\
\hline & & & undergraduate & & & & & $0.04 \%$ \\
\hline & & & students). & & & & & \\
\hline & & & $\begin{array}{l}\text { Communication } \\
\text { with schools }\end{array}$ & 52 & Participation & - & - & \\
\hline & & & $\begin{array}{l}\text { Communication } \\
\text { with guardians }\end{array}$ & 100 & School & - & - & \\
\hline & & & Referendums & 50 & Guardians & - & - & \\
\hline & & & $\begin{array}{l}\text { Posts: } \\
\text { newspapers, SMS, } \\
\text { and brochures }\end{array}$ & 1000 & $\begin{array}{c}\text { Posts: } \\
\text { newspapers, } \\
\text { SMS, and } \\
\text { brochures }\end{array}$ & - & - & \\
\hline
\end{tabular}

Tables (3), (3-1), (3-2), and (3-3) show that the achievement of the digital measurements of social responsibility domain was rated $0.04 \%$.

- The project of offering an award for the best participation by a department, faculty member, or administrator was rated $0 \%$. It achieved no indicators because these projects require special budgets. The result is consistent with Al-Afif (2005) and Al-Shuboul (2005), suggesting that financial obstacles and lack of administrative as well as supervisory support impeded the strategy implementation. It is also consistent with Al-Hammaly and AlAraby (2013) that lack of administrative as well as supervisory support impeded the strategy implementation.

- The project of activating the program of the school students' full-day visit to the College was rated ( $0 \%$ ) because the College lacked the main facilities, such as library, laboratories, spaces, and cafeteria. The result is consistent with Al-Fadli (2014) that infrastructure problems might impede the development and change at the College of Education.

- The project of conducting a project related to community service (problem-solving) was rated $(0.044 \%)$ and achievement indicators rate ranged $(0 \%-100 \%)$ because these projects need for special budgets and the difficulties associated with lack of definite work mechanisms, clear regulation, and implementable plans. The result is consistent with Sterling (2003) that insufficient resources hindered the implementation of the strategy 
and Al-Afif (2005) that the lack of funding and information, as well as old regulation hindered its implementation. It also agrees with Al-Shuboul (2005) that financial, administrative as well as supervisory obstacles impeded the strategy implementation, and with Poon (2003) that some obstacles hindered performance evaluation in terms of the evaluation and the evaluator.

\subsection{Results of the Fourth Question}

In order to answer this question, frequencies and percentages of performance indicators of funding and investment domain were estimated, as shown in tables (4), (4-1) and (4-2).

Table 4. Rate of Achieving the Performance Indicators of Funding and Investment Projects

\begin{tabular}{cllc}
\hline Project & \multicolumn{1}{c}{ Title } & \multicolumn{1}{c}{ Program } & Achievement \\
\hline M9 B30 Sh11 & Developing an executive master program & $\begin{array}{l}\text { Developing an executive } \\
\text { scientific departments }\end{array}$ & in \\
$\begin{array}{c}\text { M9 B30 Sh12 } \\
\text { Overall achievement }\end{array}$ & Increase the number of scientific chairs & Suggesting scientific chairs & $80 \%$ \\
\hline
\end{tabular}

Table (4-1). Rate of Achieving the Performance Indicators of the Project of Developing an Executive Master Program

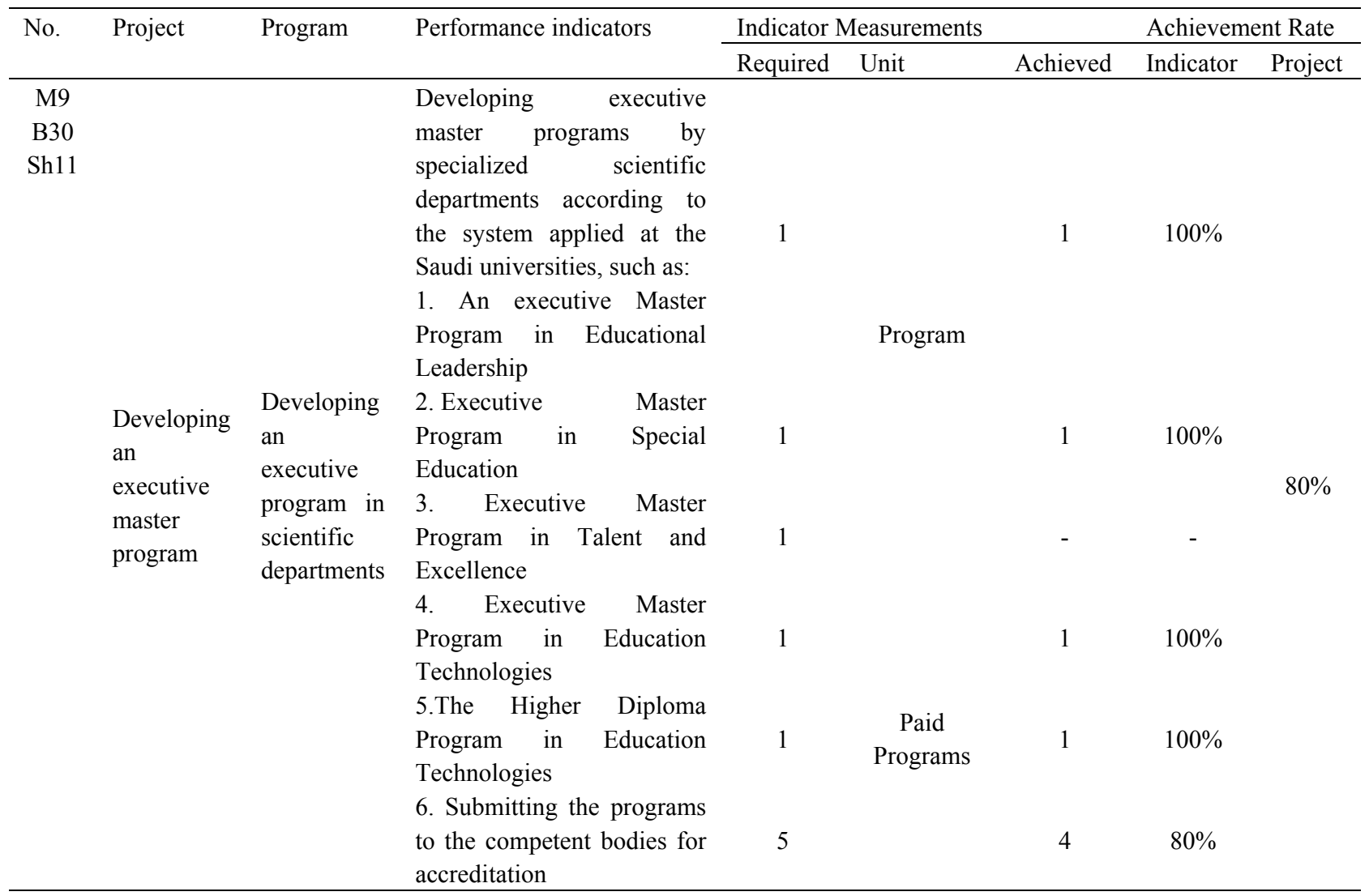


Table (4-2). Rate of Achieving the Performance Indicators of the Project of Increasing the Number of Scientific Chairs

\begin{tabular}{|c|c|c|c|c|c|c|c|c|}
\hline \multirow[t]{2}{*}{ No. } & \multirow[t]{2}{*}{ Project } & \multirow[t]{2}{*}{ Program } & \multirow{2}{*}{$\begin{array}{l}\text { Performance } \\
\text { indicators }\end{array}$} & \multicolumn{3}{|c|}{ Indicator Measurements } & \multicolumn{2}{|c|}{ Achievement Rate } \\
\hline & & & & Required & Unit & Achieved & Indicator & Project \\
\hline $\begin{array}{l}\text { M9 } \\
\text { B30 } \\
\text { Sh12 }\end{array}$ & $\begin{array}{l}\text { Increase } \\
\text { the number } \\
\text { of } \\
\text { scientific } \\
\text { chairs }\end{array}$ & $\begin{array}{l}\text { Suggesting } \\
\text { scientific } \\
\text { chairs } \\
\text { Establishing } \\
\text { the Center for } \\
\text { Diagnosis of } \\
\text { Special } \\
\text { Education }\end{array}$ & $\begin{array}{l}\text { 1. Define the vision, } \\
\text { mission, and } \\
\text { objectives of the chair. } \\
\text { 2. Explore the } \\
\text { requirements of the } \\
\text { preparation for } \\
\text { scientific chairs. } \\
\text { 3. Find a financier for } \\
\text { the scientific chair. } \\
\text { 4. Define the topics } \\
\text { and their significance. } \\
\text { 5. Define the } \\
\text { departments related to } \\
\text { the chair. } \\
6 \text {. Contact the } \\
\text { competent bodies and } \\
\text { define the topics they } \\
\text { can participate in. } \\
\text { 7. Define a number of } \\
\text { measures that keep the } \\
\text { level of the scientific } \\
\text { chair. } \\
8 \text {. Design a website } \\
\text { for the chair and } \\
\text { collection of its } \\
\text { administrative and } \\
\text { scientific information. }\end{array}$ & $\begin{array}{c}2 \\
\text { scientific } \\
\text { chairs }\end{array}$ & $\begin{array}{l}\text { scientific } \\
\text { chairs }\end{array}$ & $0 \%$ & $0 \%$ & $0 \%$ \\
\hline & & & $\begin{array}{l}\text { 9. Make a plan on } \\
\text { Establishing the } \\
\text { Center for Diagnosis } \\
\text { of Special Education }\end{array}$ & 1 Center & Center & $0 \%$ & $0 \%$ & $0 \%$ \\
\hline
\end{tabular}

Tables (4), (4-1) and (4-2) show that the achievement of the measurements of funding and investment domain was rated $(73 \%)$.

- The project of developing an executive master program was rated $80 \%$ and the achievement indicators were $(0 \%-100 \%)$, and the indicators ranged $(80 \%-100 \%)$, except for the executive master program in talent and excellence because of the department plan in an expansion. The achievement of increasing scientific chairs program was rated $(0 \%)$ because this project requires top management, and it is difficult to increase the chairs by the action administrations.

- Funding and investment is an important domain that necessitates issuing definite legislation by the top management. It is consistent with the challenges to the Ministry of Education and the attitude towards allocating services and educational outcomes in Saudi Arabia. The Ministry called for transforming these challenges into investment opportunities. This requirement matches the two Documents of Allocation Strategy established by the State in 2002 in accordance with the Supreme Economic Council (Al- Mardi, 2016). 
In order to answer the major question of the study, the obstacles involved in the tool of the study and which impede the implementation of some indicators based on the perspective of those in charge of implementing the domains and projects were listed. They were as follows:

A. Obstacles to implementing learning and education domain

- The need to educate faculty members and course coordinators on the importance of the course portfolio and its preparation.

- The need to use technical methods to facilitate the preparation of the course portfolio for easy modification and addition.

- Interaction of the students and filling the form objectively.

- Activating the role of the Units of Measurement and Evaluation due to the need for administrative organization and human expertise.

- Lack of material resources and the needs substantial for achieving and regulating some requirements.

B. Obstacles to implementing post-graduate studies domain

- The need for a committee specialized in the field of scientific research and dissemination of scientific publication culture among faculty members and post-graduate students.

- Publishing in reviewed and standardized journals due to Jeddah University.

- Lack of the faculty members' database at Jeddah University.

- Establishing a scientific journal under the College of Education to promote scientific publication at the College.

- Faculty members' low level in English language and establishing a center for teaching the English language and providing the faculty members with courses.

- Inconsistency between the schedules of the post-graduate students and the seminars, which promote their levels.

- Lack of action handbook for mission and, post-graduate studies based on mission regulation of the Saudi Universities

C. Obstacles to implementing social responsibility domain

- Allocating a budget for activating social responsibility projects.

- Material obstacles that require rapid improvement of the College infrastructure and creating an attractive environment for the students.

D. Obstacles to implementing funding and investment domain

- Organizational and material difficulties associated with launching new interdisciplinary programs that provide the College with financial resources.

- Difficulty to define the needs of civil society associations that endeavor to launch the programs, which meet their needs and provide the College with investment return.

\section{Conclusion}

The results showed that the achievement of the domains of learning and education, post-graduate studies, social responsibility, and funding was rated (28\%), (18\%), (17\%), and (50\%), respectively. The obstacles were related to the need to educate the faculty members and the course coordinators and the need to a committee specialized in scientific research and disseminating the culture of scientific publication among the faculty members and postgraduate students. Moreover, material obstacles were related to the rapid improvement of the College infrastructure and creating an attractive environment, and difficulty to define the needs of civil society associations that endeavor to launch the programs which meet their needs and provide the College with investment return.

\section{Recommendations}

The study makes the following recommendations:

- Investigating the challenges to implementing the strategic plans at the institutions of higher education.

- Publishing the strategic plan of the university throughout the paper, electronic, and verbal means to reach the whole employees. 
- Introducing the action plans to the university employees, making sure of meeting their needs and following-up the constant achievement.

- Good planning of programs and projects of the action plan and allocating adequate budgets.

- Activating the Unit of Measurement and Evaluation, as well as providing administrative information systems that support the implementation of the action plan at the College, in particular, and the University, in general.

- Honoring those in charge of implementing strategic planning in their respective areas to disseminate the positive culture and motivate others to participate.

\section{References}

Abu Eisha, G. (2007). Problems of educational planning among the principals of the public high schools in Palestine (MA. thesis). Post-graduate College, An-Najah National University, Nablus, Palestine.

Abu Sheikha, N. (2005). The employees' awareness of the objectivity of the system of performance evaluation and its relation to some personal and professional characteristics: An applied study to a random sample of public departments. Journal of Public Administration, 45(4), 376-708.

Al-Afif, A. (2005). Factors affecting strategic planning in the Jordanian Public Departments (MA. thesis). The University of Jordan, Amman, Jordan.

Al-Atawi, N. (2013). Obstacles to strategic planning at the Educational Departments in Riyadh (MA. thesis). Department of Educational Administration, Social Sciences College, Imam Muhammad ibn Saud Islamic University, Riyadh. https://doi.org/10.21474/ijar01/3002

Al-Awshen, M. (2013). Operational planning: Scientific steps to create an action plan. Riyadh: Majid Saud AlAwashen.

Al-Dajani, E. (2011). Role of strategic planning in the quality of institutional performance - A descriptive analytical study in the Palestinian Regular Universities (Ph.D. dissertation). Department of Curricula and Instruction, Damascus University, Syria.

Al-Fadli, M. (2014). Evaluation of teaching and learning quality at the College of Education, King Abdulaziz University, Jeddah. Journal of Ismailia Faculty of Education, 2(28), 291-342.

Al-Hammaly, R., \& Al-Araby, H. (2013). Obstacles to strategic planning and means of overcoming them from the perspective of the academic and administrative leaders at the University of Hail. Journal of Culture and Development, 14(71), 53-159.

Al-Looh, A. (2007). Obstacles to implementing strategic planning in Palestinian Universities in Gaza Strip (MA. thesis). Islamic University, Gaza, Palestine.

Al-Mardi, L. (2016). Evaluating the development and implementation of strategic plans. Amman: Debono Center for Teaching Thinking.

Al-Otaibi, A. (2012). Impact of strategic planning and constant improvement on the effectiveness of private institutions in Kuwait (MA. thesis). Middle East University, Jordan.

Al-Shathri, A. (2013). A proposal for school evaluation in Imam Muhammad ibn Saud Islamic University using two approaches of measurement. Journal of Education and Psychology-King Saud University, 46, 1-36. https://doi.org/10.21474/ijar01/3002

Al-Shuboul, M. (2005). The reality of strategic management in the Ministry of Education in Jordan and building a model for its development (Ph.D. dissertation). The University of Jordan, Amman, Jordan.

Awda, A., \& Malakawi, F. (1992). Fundamentals of scientific research in education and humanities (2nd ed.). Irbid: Al- Kettani Bookshop.

Cowburn, S. (2005). Strategic planning in higher education: Factor or fiction? Perspectives: Policy and Practice in Higher Education, 9(4), 103-109. https://doi.org/10.1080/13603100500357324

Damanhoury, Z. (2009). Second strategic plan (2011-2014.). Retrieved from http: //kau.edu.sa/Pages strategic

Darakka, A. (2009). Educational management and planning: New visions. Irbid: The World of Modern Books.

Dessler, G. (2004). Management leading people organization in $21^{\text {st }}$. New Jersey: Prentice Hall. 
General Administration of Planning and Administrative Development (2015). General instructions on developing the action plans of the Colleges of Majmaah University and its supporting Deanships (2012-2015) - Building report writing team. KSA: Majmaa University.

Hamdan, K., \& Idris, W. (2009). Strategy and strategic planning. Amman: Al Yazouri Publishing House.

Hoffman, R. (2007). The strategic planning process and performance relationship: does culture matter? Journal of Business Strategies, 24(1), 27-48.

John, A., \& Richard, B. (2011). Strategic management: Formulation, implementation and control (12th ed.). New York: McGraw-Hill.

Madbouli, M. (2002). School strategic planning. Cairo: Dar Almaktaba Alarabia.

Ministry of Education (2013). Handbook of action plan preparation. Kingdom of Saudi Arabia, Riyadh: Ministry of Education.

Mostafa, M. (2014). Analysis, measurement and evaluation of human performance. Cairo: Professional Experiences Center of Management.

Poon, J. (2003). Effects of performance appraisal politics on job satisfaction and Turn over intention. Journal Personal Review, 33(3), 322-334. https://doi.org/10.1108/00483480410528850

Rudd, J., Greenley, G., \& Beatson, A. (2008). Strategic planning and performance: Extending the debate. Journal of Business Research, 61(2), 99-108. https://doi.org/10.1016/j.jbusres.2007.06.014

Shawish, M. (2005). Human resource management- personnel management. Egypt: Al-Shorouk.

Shuwaikh, A. (2007). Reality of strategic planning in technical education institutions in Gaza Governorate (MA. thesis). Islamic University, Gaza, Palestine.

Sterling, J. (2003). Translating strategy into effective implementation: Dispelling the myths and highlighting what works. Strategy \& Leadership, 31(3), 27-34. https://doi.org/10.1108/10878570310472737

Sultan, J. (2010). Strategic thinking and overcoming the present predicament. Mansoura: Umm Al-Qura Foundation for Translation and Distribution.

Yasin, S. (2002). Strategic management. Amman: Al Yazouri Publishing House.

Appendix (1): Sample of the action plan of the domain

\begin{tabular}{|l|l|l|l|l|l|l|l|l|}
\hline No. & Project & Program & \multirow{2}{*}{$\begin{array}{c}\text { Performance } \\
\text { indicators }\end{array}$} & & \multicolumn{2}{|c|}{ Indicator Measurements } & \multicolumn{2}{|c|}{ Achievement Rate } \\
\cline { 5 - 8 } & & & & Required & Unit & Achieved & Indicator & Project \\
\hline & & & & & & & & \\
\hline
\end{tabular}

Appendix (2): Sample of the follow-up form of the action plan of the domain

\begin{tabular}{|c|c|c|c|c|c|c|c|c|}
\hline \multirow[t]{2}{*}{ No. } & \multirow[t]{2}{*}{ Project } & \multirow[t]{2}{*}{ Program } & \multirow{2}{*}{$\begin{array}{l}\text { Performance } \\
\text { indicators }\end{array}$} & \multicolumn{3}{|c|}{ Indicator Measurements } & \multicolumn{2}{|c|}{ Achievement Rate } \\
\hline & & & & Required & Unit & Achieved & Indicator & Project \\
\hline & & & & & & & & \\
\hline & & & & & & & & \\
\hline & & & & & & & & \\
\hline
\end{tabular}

